\title{
Bimbingan Kelompok dengan Pengajaran Formula ABCDE Pendekatan Rasional Emotif Behavior untuk Meningkatkan Self Efficacy Mahasiswa Calon Guru
}

\author{
Ismarini Bekti Setiani, Agus Taufiq, S. Suherman \\ Program Studi Magister Bimbingan dan Konseling, Sekolah Pascasarjana, Universitas Pendidikan Indonesia, \\ Jl. Dr. Setiabudhi No. 229, Bandung, Jawa Barat, Indonesia 40154 \\ E-mail: ismarinibekti_setiani@yahoo.com
}

Artikel diterima: 28 November 2016; direvisi 18 Januari 2017; disetujui 28 Februari 2017

\begin{abstract}
Abstrak: Tujuan penelitian ini yaitu merumuskan dan menyusun desain intervensi bimbingan kelompok dengan pengajaran formula $\mathrm{ABCDE}$ pendekatan rasional emotif behavior serta menguji efektivitas desain intervensi dalam meningkatkan self efficacy calon guru di Departemen Pendidikan Teknologi Agroindustri Universitas Pendidikan Indonesia (UPI). Penelitian menggunakan mixed methods dengan strategi embedded konkuren (kuantitatif sebagai metode primer dan kualitatif sebagai metode sekunder). Teknik Analisis data menggunakan analisis data kuantitatif (primer) dan kualitatif (sekunder). Hasil penelitian menunjukkan bahwa secara kuantitatif, bimbingan kelompok dengan pengajaran formula ABCDE pendekatan rasional emotif behavior belum efektif dalam meningkatkan self efficacy mahasiswa calon guru dengan beberapa faktor penyebab. Dari data kualitatif didapatkan bahwa mahasiswa menyadari akan masalahnya, menyadari ada penyebab keyakinan irasional penyebab masalah, memahami dalam mengatasinya sehingga mahasiswa merasa semakin yakin akan kemampuan untuk menjadi guru. Peneliti selanjutnya diharapkan menindaklanjuti penelitian ini dengan menerapkan desain intervensi kepada mahasiswa yang memiliki self efficacy ketegori rendah dan sedang.
\end{abstract}

Kata kunci: bimbingan kelompok; rasional emotif behavior; self efficacy

Kesiapan diri dari calon guru untuk menjadi guru dipengaruhi keyakinan akan kemampuan untuk menjadi seorang guru. Kesiapan diri seseorang dipengaruhi tingkat keyakinan terhadap kemampuan diri sendiri atau efikasi diri (Arifin dkk., 2014). Berdasarkan studi pendahuluan pada mahasiswa di Universitas Pendidikan Indonesia Departemen Pendidikan Teknologi Agroindustri didapatkan bahwa mahasiswa kurang yakin akan kemampuan menjadi guru diakibatkan karena cara berfikir yang salah (irasional) dari hasil pengalaman mengajarnya. Ketidakyakinan akan kemampuan diri disebut dengan self efficacy.

Self-efficacy adalah penilaian dari individu tentang kemampuan mereka untuk sukses melakukan tugas atau pekerjaan. Bandura dalam (Ghufron \& Rini, 2011: 75) mengatakan bahwa efikasi diri pada dasarnya adalah hasil dari proses kognitif berupa keputusan, keyakinan, atau pengharapan tentang sejauh mana individu memperkirakan kemampuan dirinya dalam melaksanakan tugas atau tindakan tertentu yang diperlukan untuk mencapai hasil yang diinginkan. Sebagai calon guru efikasi diri sangat diperlukan untuk keberhasilan dalam mengajarkan ilmu yang telah didapatkan selama di bangku kuliah (Arifin dkk., 2014).

Ada empat kompetensi yang harus dimiliki oleh seorang guru yang salah satunya adalah kompetensi kepribadian. Kompetensi kepribadian merupakan kemampuan kepribadian yang mantap, stabil, dewasa, arif, dan berwibawa, menjadi teladan bagi peserta didik, dan berakhlak mulia. Salah 
satu rincian dari kompetensi ini adalah seorang guru harus memiliki rasa bangga dan rasa percaya diri menjadi guru (Permendiknas, 2007). Kepercayaan atau keyakinan terhadap diri sendiri bahwa seorang mampu menjadi seorang guru dinamakan dengan self efficacy.

Self efficacy berpengaruh pada pembelajaran guru (Arslan, 2012). Lian \& Richardson (2009) menyatakan bahwa guru dengan self-efficacy tinggi menunjukkan komitmen yang lebih besar untuk prestasi siswa, punya harapan yang tinggi bagi siswa mereka, dan menimbulkan prestasi siswa lebih besar. Fenomena ini penting untuk dicermati karena untuk mempersiapkan calon guru agar siap menjadi guru yang berkualitas nantinya. Persiapan tersebut salah satunya dengan meningkatkan dan mempertahankan keyakinan terhadap kemampuan (self efficacy) untuk menjadi seorang guru. Upaya yang dapat dilakukan dengan memberikan pelayanan bimbingan kelompok dengan pengajaran formula $\mathrm{ABCDE}$ pendekatan rasional emotif behavior. Dengan bimbingan kelompok akan lebih optimal karena semua mahasiswa calon guru baik yang memiliki self efficacy rendah maupun tinggi mendapatkan manfaat dari kegiatan ini sehingga bimbingan kelompok dimungkinkan lebih efektif digunakan dan lebih efisien dalam hal waktu penanganan. Gazda dalam Aini \& Nursalim (2012) mengemukakan bahwa kegiatan bimbingan kelompok adalah kegiatan yang berupa penyampaian informasi yang tepat mengenai masalah pendidikan, pekerjaan, pemahaman pribadi. Informasi tersebut diberikan terutama dengan tujuan memperbaiki dan mengembangkan pemahaman diri individu dan pemahaman terhadap orang lain (Aini \& Nursalim, 2012). Dengan bimbingan kelompok mahasiswa akan mendapatkan pembinaan dan informasi positif untuk peningkatan self efficacy yang rendah/ sedang dan mempertahankan self efficacy yang sudah tinggi pada mahasiswa. Dari studi pendahuluan kepada mahasiswa baik yang belum praktek maupun yang telah mengikuti praktek mengajar didapatkan bahwa mereka memiliki keyakinan irasional yang menyebabkan kurangnya keyakinan menjadi guru. Willis (2014:76) pendekatan rasional emotif bertujuan memperbaiki dan mengubah sikap, persepsi, cara berfikir, keyakinan serta pandangan klien yang irasional menjadi rasional, sehingga ia dapat mengembangkan diri dan mencapai realisasi yang optimal. Pendekatan rasional emotif dapat digunakan dalam kelompok. Dalam pendekatan ini terdapat formula ABCDE yang dapat membantu siswa dalam menggali masalah yang dialami dari kejadian atau akibat dan kepercayaan atau keyakinan yang mendasari terjadinya suatu peristiwa, kejadian yang awalnya tidak mungkin terjadi menjadi mungkin terjadi sehingga siswa memiliki keyakinan terhadap kemampuan diri (Handika, 2014).

Bimbingan kelompok dapat merupakan awal dari konseling individual, dan bimbingan kelompok dapat menjadi pelengkap dari teknik konseling individual (Natawidjaja, 1987). Pendekatan rasional emotif behavior merupakan salah satu bentuk pendekatan aktif-direktif yang menyerupai proses pendidikan (education) dan pengajaran (teaching). Konseling Rasional Emotif (RET) merupakan salah satu bentuk konseling aktif-direktif yang menyerupai proses pendidikan (education) dan pengajaran (teaching) dengan mempertahankan dimensi kognitif (pikiran) dan behavior (perilaku) dari pada perasaan (Corey, 2009:247). Pendekatan ini membantu mengubah keyakinan irasional penyebab masalah dengan keyakinan rasional dengan memberikan pengajaran, penjelasan dan pemahaman kepada konseli mengenai konsep atau formula ABCDE sehingga konseli pada akhirnya akan dapat mengatasi masalah sendiri dengan pemahaman yang telah dimilikinya tersebut. Dalam langkah konseling rasional emotif behavior terdapat langkah dasar dan awal yang harus dipahami oleh konseli yaitu penjelasan dan pengajaran tentang formula ABCDE. Jika formula ABCDE telah dipahami oleh konseli maka langkah menuju layanan konseling individu/kelompok akan mudah dilakukan dan diharapkan konseli dapat mengatasi masalahnya sendiri dengan pemahaman yang telah diterimanya. Pemberian pengajaran untuk memahamkan mahasiswa terkait formula ABCDE untuk masalah self efficacy calon guru maka dilakukan layanan bimbingan kelompok dengan pengajaran formula ABCDE pendekatan rasional emotif behavior. Dengan pengajaran dan pemahaman tersebut diharapkan mahasiswa calon guru mendapatkan bekal untuk mengatasi masalahnya sendiri terkait meningkatkan dan mempertahankan self efficacy calon guru. 
Intervensi yang dilakukan yaitu memberikan bimbingan kelompok dengan pengajaran formula ABCDE pendekatan rasional emotif behavior yang dirumuskan untuk mengembangkan self efficacy yang rendah/sedang dan memelihara self efficacy mahasiswa yang tinggi. Mahasiswa yang sudah memiliki self efficacy tinggi akan mendapatkan manfaat yaitu untuk pencegahan dan semakin memperkuat atau mempertahankan self efficacy yang telah dimilikinya. Hal ini dikarenakan, self efficacy bersifat dinamis yang berubah dari waktu ke waktu dan dapat dipengaruhi oleh pengalaman (Raelin dkk, 2014). Begitu juga dengan mahasiswa self efficacy rendah/sedang akan mendapatkan manfaat untuk meningkatkan self efficacynya.

Penelitian ini difokuskan pada bimbingan kelompok dengan pengajaran formula ABCDE pendekatan rasional emotif behavior untuk meningkatkan dan mempertahankan self efficacy mahasiswa calon guru. Self efficacy menjadi seorang guru pada mahasiswa calon guru dapat didefinisikan sebagai keyakinan pada kemampuan diri mahasiswa dalam melaksanakan tugas sebagai guru di masa mendatang sehingga mampu mengatasi hambatan yang sulit dalam proses persiapan menjadi seorang guru yaitu terkait strategi pembelajaran, pengelolaan kelas, dan keterlibatan dengan siswa. Bimbingan kelompok dengan pengajaran formula ABCDE pendekatan rasional emotif behavior dalam penelitian ini didefinisikan sebagai layanan bimbingan melalui serangkaian kegiatan pemberian bantuan dari peneliti sebagai konselor kepada sekelompok mahasiswa (konseli) secara berkesinambungan dengan mengajarkan formula ABCDE pendekatan rasional emotif behavior sehingga mahasiswa memahami masalah yang dihadapi dan mendapatkan informasi serta pemahaman untuk mengatasi masalah sendiri dengan menerapkan pemahaman mengenai formula $\mathrm{ABCDE}$ dalam menyelesaikan masalahnya yaitu terkait dengan self efficacy menjadi guru. Adapun tujuan dari penelitian ini adalah merumuskan dan menyusun desain intervensi bimbingan kelompok dengan pengajaran formula $\mathrm{ABCDE}$ pendekatan rasional emotif behavior serta menguji efektivitas desain intervensi dalam meningkatkan self efficacy calon guru di Departemen Pendidikan Teknologi Agroindustri UPI.

\section{METODE}

Metode yang digunakan dalam penelitian ini adalah mixed methods, yaitu menggabungkan metode kuantitatif dan metode kualitatif. Penelitian ini menggunakan metode kuantitatif sebagai metode penelitian utama (primer) dan metode penelitian kualitatif sebagai pendukung. Strategi ini merupakan strategi embedded konkuren, yaitu strategi pada mix methods yang menerapkan satu tahap pengumpulan data kuantitatif dan kualitatif dalam satu waktu, memiliki metode primer (metode utama yang memandu dan lebih dominan digunakan dalam penelitian) dan metode sekunder (yang memainkan peran pendukung). Metode penelitian kuantitatif digunakan untuk mengetahui efektivitas bimbingan kelompok dengan pengajaran formula ABCDE pendekatan rasional emotif behavior, sedangkan metode kualitatif digunakan pada tahap studi pendahuluan dan mengeksplorasi proses intervensi yang diterapkan/ dilaksanakan untuk mengetahui peningkatan self efficacy mahasiswa calon guru selama diterapkan intervensi sampai selesainya intervensi.

Pada metode primer penelitian ini yaitu kuantitatif, desain yang digunakan adalah quasi experiment design yang dalam pelaksanaannya tidak menggunakan penugasan acak (random assignment), melainkan menggunakan kelompok yang sudah terbentuk (intact group). Hal ini sesuai pernyataan Creswell (2012) bahwa "Quasi-experiments include assignment, but not random assignment of participants to groups". Rancangan quasi experiment design yang digunakan adalah nonequivalent pretest-posttest control group design. Pada metode sekunder penelitian ini yaitu kualitatif, pengumpulan data menggunakan pedoman observasi lapangan, wawancara, evaluasi diri mahasiswa selama kegiatan yang berupa tanggapan mahasiswa terhadap kegiatan yang telah dilakukan, dan dokumentasi/rekaman untuk mengeksplorasi proses berlangsungnya intervensi.

Penelitian ini dilakukan di Universitas Pendidikan Indonesia, dengan populasi penelitian adalah mahasiswa dari dua program studi yang mempersiapkan mahasiswa calon guru di sekolah kejuruan yaitu Pendidikan Teknologi Agroindustri dan Pendidikan Manajemen Bisnis yang sudah melakukan 
PPL (Praktek mengajar di sekolah) yaitu sejumlah 30 mahasiswa. Pengambilan sampel metode campuran menggunakan strategi dasar dari dari lima tipologi sampling metode campuran. Strategi dasar di dalamnya sampling kuantitatif dan sampling kualitatif dikombinasikan (Creswell, 2010: 327). Pengambilan sampel kuantitatif dilakukan dengan menggunakan non-probabilistic sampling. Jumlah responden penelitian secara lebih rinci disajikan pada tabel 1 .

Metode pengumpulan data yang digunakan dalam penelitian ini adalah metode pengumpulan data primer yaitu data kuantitatif dan metode pengumpulan data sekunder yaitu data kualitatif. Data kuantitatif diperoleh menggunakan skala self efficacy mahasiswa calon guru. Sedangkan data kualitatif diperoleh menggunakan pedoman observasi lapangan, pedoman wawancara, evaluasi diri mahasiswa selama kegiatan, dan audio-visual. Dalam penelitian ini analisis dilakukan berdasarkan pendekatan kuantitatif (analisis angka-angka secara deskriptif dan inferensial) dan kualitatif (deskripsi dan analisis teks atau gambar secara tematik). Proses analisis data kuantitatif dilakukan dengan menggunakan teknik U-Mann-Withney (dengan SPSS) karena jenis data ordinal. Selain secara kuantitatif, analisis juga dilakukan dengan kualitatif yaitu deskripsi dan analisis teks atau gambar secara tematik (ada penjelasan untuk mengetahui perkembangan konseli setiap dilakukan treatment).

\section{HASIL}

Pelaksanaan intervensi bimbingan kelompok dengan pengajaran formula ABCDE pendekatan rasional emotif behavior berjalan lancar sesuai dengan rancangan intervensi yang telah disusun. Intervensi ini belum efektif secara kuantitatif untuk meningkatkan self efficacy mahasiswa calon guru. Hasil uji hipotesis disajikan dalam tabel 2 sedangkan hasil pretest dan posttest self efficacy mahasiswa calon guru kelompok eksperimen dan kontrol disajikan pada tabel 3.

Dilihat dari data kualitatif terlihat mahasiswa menyadari ada penyebab keyakinan irasional penyebab masalah dan memahami cara mengatasinya sehingga mahasiswa merasa ada keyakinan akan kemampuan untuk menjadi guru.

\section{PEMBAHASAN}

Dari hasil data kuantitatif menunjukkan intervensi yang dilakukan belum efektif dalam meningkatkan self efficacy mahasiswa calon guru. Ada beberapa faktor yang memengaruhi intervensi sehingga belum efektif dalam meningkatkan self efficacy secara kuantitatif dalam penelitian ini diantaranya: (1) self efficacy mahasiswa sebagian besar sudah dalam kategori tinggi sehingga seharusnya desain intervensi ini lebih tepat dilakukan kepada mahasiswa yang skor rendah dan sedang; (2) kemampuan peneliti sebagai konselor yang melakukan intervensi dirasa masih kurang dan banyak kekurangan seperti ada yang terlewat tahapannya tidak dilakukan seperti tugas dan tanggung jawab anggota belum dijelaskan sehingga peraturan atau tata tertib pelaksanaan tiap sesi belum optimal dilakukan anggota kelompok, belum mentargetkan waktu pada masing-masing tahapan, dalam menjelaskan suara peneliti kurang terdengar keras berdampak beberapa anggota bertanya dan masih harus dijelaskan ulang. Jika dilihat dari data kuantitatif terdapat peningkatan self efficacy mahasiswa calon guru karena mahasiswa telah memiliki keyakinan kemampuan dalam strategi pembelajaran, pengelolaan kelas, dan keterlibatan siswa ketika berkarir menjadi guru di masa mendatang.

Keyakinan kemampuan mahasiswa calon guru dalam strategi pembelajaran, pengelolaan kelas, dan keterlibatan siswa mengacu pada tingkatan kesulitan tugas yang mahasiswa merasa mampu menghadapi (level), seberapa kuat keyakinan kemampuan dalam usaha menghadapi tuntutan tugas menjadi guru (strength), dan seberapa luas keyakinannya dalam menerapkan kemampuannya apakah terbatas pada situasi tertentu atau pada serangkaian aktivitas dan situasi yang bervariasi ketika menjadi guru (generality). Self efficacy pada diri tiap individu akan berbeda antara satu individu dengan yang lainnya berdasarkan level, strength, dan generality (Bandura, 1997). Berdasarkan data kualitatif menunjukkan bahwa mahasiswa kelompok eksperimen memahami dan menerapkan keyakinan 
Tabel 1 Jumlah Responden Penelitian

\begin{tabular}{llc}
\hline \multicolumn{1}{c}{ Tahap Penelitian } & \multicolumn{1}{c}{ Program Studi } & Jumlah Mahasiswa \\
\hline Studi Pendahuluan & Pend. Teknologi Agroindustri & 15 \\
\hline & Pend. Manajemen Bisnis & 15 \\
\hline & Jumlah Total & $\mathbf{3 0}$ \\
\hline Uji Efektivitas Desain & Kelompok Eksperimen & 6 \\
\hline & Kelompok Kontrol & 6 \\
\hline & Jumlah Total & $\mathbf{1 2}$ \\
\hline
\end{tabular}

Tabel 2 Hasil Uji Hipotesis

\begin{tabular}{ccccc}
\hline $\begin{array}{c}\text { Mann-Whitney } \\
\mathbf{U}\end{array}$ & $\mathbf{Z}$ & $\begin{array}{c}\text { Asymp.Sig. } \\
\text { (2-tailed) }\end{array}$ & $\begin{array}{c}\text { Asymp.Sig. } \\
\text { (1-tailed) }\end{array}$ & Kesimpulan \\
\hline 11.000 & -1.123 & 0.261 & 0.130 & Terima $\mathrm{H}_{0}$ \\
\hline
\end{tabular}

Tabel 3 Self Efficacy Mahasiswa Calon Guru Kelompok Eksperimen dan Kontrol

\begin{tabular}{cccccc}
\hline $\begin{array}{c}\text { Kode Mahasiswa } \\
\text { Kelompok Eksperimen }\end{array}$ & Pretest & Posttest & $\begin{array}{c}\text { Kode Mahasiswa } \\
\text { Kelompok Kontrol }\end{array}$ & Pretest & Posttest \\
\hline E1 & 114 & 111 & K1 & 76 & 90 \\
E2 & 98 & 102 & K2 & 107 & 105 \\
E3 & 84 & 110 & K3 & 79 & 106 \\
E4 & 118 & 116 & K 4 & 103 & 106 \\
E5 & 85 & 89 & K 5 & 79 & 76 \\
E6 & 80 & 94 & K6 & 90 & 92 \\
\hline Jumlah & $\mathbf{5 7 9}$ & $\mathbf{6 2 2}$ & Jumlah & $\mathbf{5 3 4}$ & $\mathbf{5 7 5}$ \\
\hline
\end{tabular}

rasional dalam persiapan menjadi guru dan menghadapi tuntutan ketika saatnya berkarir menjadi guru. Cara pandang dan berpikir mahasiswa menjadi rasional dalam menghadapi segala tuntutan dan tantangan menjadi guru. Dengan cara berpikir yang rasional terhadap tuntutan dan tantangan menjadi guru maka mahasiswa merasa yakin akan kemampuan menjadi guru semakin kuat dan luas tidak hanya terbatas pada situasi tertentu akan tetapi dalam situasi yang bervariasi ketika menjadi guru. Keyakinan terhadap kemampuan yang kuat dan tinggi tersebut menandakan semakin tinggi dan kuatnya self efficacy guru yang dimiliki mahasiswa. Hal ini sesuai pendapat Bandura (1997:3) bahwa disfungsi dan penderitaan yang dialami individu disebabkan karena cara berfikirnya. Apabila individu berfikir irasional (negatif) maka menjadi pribadi yang bermasalah, sedangkan apabila individu berfikir rasional (positif) maka menjadi pribadi yang sehat tidak terganggu kehidupan efektif sehari-harinya. Hal ini sesuai pernyataan dari Corey (2009) bahwa tingkah laku bermasalah adalah tingkah laku yang didasarkan, dikendalikan oleh cara berfikir yang irasional. Ketidakyakinan mahasiswa pada kemampuan yang dimiliki untuk menjadi guru (self efficacy mahasiswa calon guru) disebabkan karena mahasiswa memiliki cara berfikir/keyakinan yang irasional. Dengan demikian, self efficacy mahasiswa calon guru meningkat dan kuat ketika mahasiswa rmemiliki dan menerapkan cara berfikir/ keyakinan yang rasional dalam proses persiapan dan berkarir menjadi guru di masa mendatang. Self-efficacy bersifat dinamis yang berubah dari waktu ke waktu dan dapat dipengaruhi oleh pengalaman (Raelin dkk, 2014).

Walaupun kategori skor secara analisis kuantitatif menunjukkan kategori yang sedang bahkan tinggi pada awalnya, tetapi secara kualitatif dapat dilihat bahwa masih ada ketidakyakinan akan kemampuan menjadi guru walaupun hanya sedikit atau tidak semua dimensi self efficacy guru. Setelah mengikuti bimbingan kelompok dengan pengajaran formula ABCDE pendekatan rasional emotif behavior, mahasiswa memperoleh pemahaman baru terkait masalah self efficacy guru, penyebab utama masalah tersebut yaitu adanya keyakinan irasional dan cara mengatasinya 
untuk meningkatkan, memperkuat dan mempertahankan self efficacy guru pada diri mahasiswa. Berdasarkan dimensi self efficacy guru dari Tschannen-Moran, Woolfolk Hoy \& Hoy's (1998), tiap mahasiswa memiliki self efficacy guru pada dimensi yang berbeda-beda.

\section{Efikasi dalam Strategi Pengajaran (Efficacy for Instructional Strategies)}

Sebagian besar mahasiswa kurang yakin akan kemampuannya memilih dan menggunakan strategi yang tepat agar materi dapat dipahami oleh semua siswa. Mahasiswa merasa kurang menguasai strategi pengajaran ketika tampil dalam praktek mengajar. Terdapat dua strategi pengajaran yaitu pendekatan yang terpusat pada guru (ceramah, diskusi, cerita, dll) dan pendekatan yang terpusat pada siswa (strategi belajar kelompok, peer teaching, dsb). Sebagai guru dituntut dapat menggunakan strategi secara efektif dan tepat agar materi dapat tersampaikan kepada siswa. Tuntutan tersebut yang membuat mahasiswa calon guru menjadi ragu akan kemampuannya menjadi guru. Ketidakyakinan akan kemampuan disebabkan cara berfikir yang irasional terhadap situasi atau tantangan dan tuntutan menjadi seorang guru. Dengan berubahnya cara berfikir mahasiswa menjadi rasional (positif) maka berpengaruh pada semakin yakinnya mahasiswa terhadap kemampuannya menjadi guru. Mahasiswa memiliki cara pandang yang positif terhadap tantangan apapun yang dihadapi dalam mempersiapkan dan nantinya berkarir menjadi guru. Menjadi guru butuh proses usaha dan butuh belajar dari pengalaman khususnya dalam menerapkan strategi pengajaran. Dengan demikian, mahasiswa calon guru berkeyakinan kuat (strength) mampu menggunakan strategi pengajaran ketika berkarir menjadi guru sesulit apapun (level) dan dimanapun mengajarnya akan mampu menerapkannya (generality).

\section{Efikasi dalam Manajemen Kelas (Efficacy for Classroom Management)}

Ada beberapa mahasiswa yang kurang yakin terhadap kemampuannya dalam mengelola/ manajemen kelas. Keyakinan ini merupakan keyakinan guru dalam menciptakan dan menjaga aktivitas pembelajaran di kelas agar berjalan dengan lancar. Manajemen kelas mencakup kemampuan seorang guru dalam mengatur kelas dan mengelola perilaku siswa di kelas agar tercipta lingkungan belajar yang tertib dan teratur. Berdasarkan penelitian Leyser (2011) menunjukkan bahwa self efficacy yang tinggi dikaitkan dengan strategi manajemen kelas yang lebih positif. Keyakinan ini membutuhkan belajar dari pengalaman untuk berhasil menerapkannya. Brandon (2000) menyatakan dalam penelitiannya bahwa self efficacy calon guru secara signifikan lebih tinggi setelah berpartisipasi dalam praktek mengajar dibandingkan sebelum mengikuti praktek mengajar. Hal ini menunjukkan pengalaman berpengaruh kuat terhadap self efficacy mahasiswa calon guru. Mahasiswa menumbuhkan pandangan positif (rasional) pada diri terhadap pengalamannya dalam mengajar terkait pengelolaan kelas. Self efficacy membutuhkan pengalaman positif ataupun negatif tetapi ditanggapi dengan cara pandang yang positif agar meningkat dan kuat. Pengalaman keberhasilan merupakan pengaruh besar pada self efficacy individu karena didasarkan pada pengalaman individu secara nyata (Bandura dalam Ghufron \& Rini, 2011: 78). Kelas dengan siswa yang sulit diatur merupakan tantangan sendiri bagi guru untuk berhasil dalam menangani hal tersebut. Maka dari itu dibutuhkan cara pandang yang positif (rasional) dalam menghadapi tantangan tersebut. Dengan berfikir rasional maka akan dapat memberikan emosi dan perilaku yang positif dalam bertindak menghadapi tantangan tersebut sehingga akan jauh lebih dekat dengan keberhasilan.

\section{Efikasi dalam Keterlibatan Siswa (Efficacy for Student Engagement)}

Beberapa mahasiswa merasa ragu dan tidak yakin akan kemampuannya yang berhubungan dengan keberhasilan siswa dalam pengajarannya. Mahasiswa mengeluhkan pada diri sendiri atas kekurangannya dalam memahami keadaan dan karakter siswanya serta ketika memotivasi siswa dalam memahami pelajaran sehingga dapat menjadi penghalang dalam mengembangkan dan mengarahkan siswanya mencapai prestasi. Keyakinan kemampuan diri dalam keterlibatan siswa terkait keyakinan kemampuan guru dalam menangani hal-hal yang berhubungan dengan keterlibatan siswa pada proses 
pembelajaran yang akan mengarahkan siswa untuk mencapai prestasi yang baik. Hal ini merupakan proses yang membutuhkan waktu dan usaha agar semua siswa dapat terlibat positif dalam proses pengajarannya. Usaha tersebut apabila diikuti dengan berfikir positif (rasional) maka akan lebih berhasil dan bahagia dalam menjalaninya. Jika berfikir rasional maka hal tersebut akan dipandang sebagai suatu tantangan yang harus dihadapi bukan dihindari dan diusahakan dengan belajar dari pengalaman terus menerus untuk menjadi lebih baik. Bandura (1997) menyatakan bahwa individu yang memiliki self efficacy yang tinggi memiliki ciri-ciri yaitu mampu menangani masalah yang mereka hadapi secara efektif, yakin terhadap kesuksesan dalam menghadapi masalah atau rintangan, masalah dipandang sebagai suatu tantangan yang harus dihadapi bukan untuk dihindari, gigih dalam usahanya untuk menyelesaikan masalah, percaya pada kemampuan yang dimilikinya, cepat bangkit dari kegagalan yang dihadapinya, suka mencari situasi yang baru. Jika melihat dari ciri-ciri individu yang memiliki self efficacy tinggi tersebut maka kesemuanya dilingkupi oleh satu faktor penyebab yaitu adanya keyakinan rasional yang dimiliki terhadap situasi apapun yang dihadapinya khususnya terkait berkarir menjadi guru.

Pada kelompok eksperimen yang diberikan bimbingan kelompok dengan pengajaran formula ABCDE pendekatan rasional emotif behavior, mahasiswa menangani, memperkuat dan memelihara self efficacy lebih cenderung dari dalam diri individu. Dengan demikian, akan jauh lebih kuat kalau dasarnya diawali dari dalam dirinya sendiri, potensi untuk terpengaruh lingkungan yang membawa dampak buruk terhadap self efficacy akan sulit memengaruhinya. Dengan alasan bahwa self efficacy dapat ditumbuhkan, dipahami dan dipelajari melalui empat sumber (faktor penyebab) yang memengaruhi self efficacy pada seseorang yaitu pengalaman keberhasilan, pengalaman vicarious (model sosial), persuasi sosial, keadaan emosi. Bandura dalam Velthuis (2014) "People's beliefs about their self-efficacy can increase based upon four main sources of information". Sumber yang paling dasar yang menjadi penyebab self efficacy pada seseorang adalah sumber yang berupa pengalaman keberhasilan. Hal ini dikarenakan pengalaman keberhasilan seorang individu didasarkan pada pengalaman-pengalaman pribadi individu secara nyata dan langsung dialami individu yang berupa keberhasilan dan kegagalan.

Bimbingan kelompok merupakan cara memperluas self efficacy melalui pengaruh teman sebaya. Layanan bimbingan kelompok efektif dalam upaya meningkatkan self efficacy siswa (Putra dkk., 2013). Hasil penelitian yang dilakukan terhadap kelompok eksperimen dan kelompok kontrol mengenai self efficacy siswa menunjukkan adanya peningkatan pada kelompok eksprimen secara signifikan. Hal ini membuktikan bahwa bimbingan kelompok dapat digunakan untuk meningkatkan self efficacy individu. Dalam hubungan dengan teman sebaya, mereka memperluas pengetahuan diri mengenai kemampuannya (Bandura, 1997). Teman sebaya menyediakan fungsi efficacy yang penting. Mereka yang paling berpengalaman dan berkompeten dapat menjadi model efficacy dalam berpikir dan berperilaku.

Mahasiswa calon guru termasuk ke dalam masa dewasa yaitu masa dewasa awal. Masa dewasa awal merupakan periode ketika seseorang harus belajar untuk menangani banyak tuntutan baru yang muncul dari hubungan persahabatan (teman sebaya), hubungan pernikahan, kedudukan sebagai orang tua, dan karir pekerjaan (Bandura, 1997). Seperti dalam tugas penguasaan yang lebih dulu (pada perkembangan sebelumnya), self efficacy berperan penting terhadap pencapaian kemampuan dan pencapaian kesuksesan lebih lanjut. Mereka yang memasuki kedewasaan dengan sedikit dibekali keahlian dan terganggu oleh ketidakyakinan diri menemukan banyak aspek dalam hidupnya penuh stress dan kemurungan. Mempersiapkan sampai memulai karir yang produktif memberikan tantangan dalam masa dewasa awal. Self efficacy menyumbang terhadap pengembangan karir dan kesuksesan dalam menguasai suatu keahlian termasuk juga dalam pengembangan karir menjadi guru.

Self efficacy menjadi seorang guru pada mahasiswa calon guru dapat didefinisikan sebagai keyakinan pada kemampuan diri mahasiswa dalam melaksanakan tugas sebagai guru di masa mendatang sehingga mampu mengatasi hambatan yang sulit dalam proses persiapan menjadi seorang guru yaitu dalam strategi pembelajaran, pengelolaan kelas, dan keterlibatan dengan siswa. 
Self efficacy berpengaruh pada sikap calon guru pendidikan jasmani terhadap pekerjaan pengajaran (Eroglu, 2015). "Teachers' perceptions of self-efficacy would influence their preferences for a problem-solving stylein conflict situations with students" (Pinchevsky \& Bogler, 2014). Hal ini menunjukan bahwa pentingnya self efficacy menjadi guru pada mahasiswa calon guru. Self efficacy juga penting dimiliki oleh seorang yang sudah berprofesi sebagai guru. Teacher efficacy merupakan faktor yang penting dalam meningkatkan kualitas pendidikan dan perbaikan pendidikan (Goddard, Hoy \& Woolfolk Hoy, 2000). Gibson \& Dembo (dalam Tschannen-Moran, Woolfolk Hoy \& Hoy's, 2001) mendefinisikan teacher efficacy sebagai penilaian guru terhadap kemampuannya untuk memberikan perubahan positif pada siswa. Dengan demikian, mahasiswa calon guru penting untuk memiliki self efficacy guru yang tinggi dan kuat dalam proses persiapan menjadi guru maupun saat sudah berkarir sebagai guru di masa mendatang.

Penelitian ini memiliki keterbatasan dalam pelaksanaannya diantaranya: (1) penelitian dilakukan oleh peneliti bersama mitra peneliti sehingga belum melibatkan secara efektif peran sebenarnya konselor perguruan tinggi saat pemberian intervensi; (2) kemampuan peneliti dalam melaksanakan intervensi dirasa masih kurang karena ada tahap yang lupa dilakukan dan kurang bisa memanajemen waktu intervensi; (3) sulit menentukan jadwal kegiatan karena sampel penelitian adalah mahasiswa tingkat akhir yang sedang memiliki kesibukan tugas akhir dan jarang ke kampus; (4) self efficacy mahasiswa yang mengikuti penelitian ini sebagian besar sudah baik dan tinggi sehingga secara kuantitatif menyatakan tidak ada peningkatan self efficacy dan sebaiknya lebih tepat untuk yang rendah dan sedang; (5) instrumen yang digunakan dirasa masih kurang mampu mengungkap dan mengontrol self efficacy dalam jangka waktu panjang khususnya untuk melihat perubahan perilaku pada mahasiswa setelah intervensi atau dengan kata lain perlu waktu penelitian yang lebih lama untuk mengetahui perkembangan mahasiswa setelah intervensi; (6) keterbatasan dalam meminimalisir adanya ancaman validitas yang memengaruhi hasil penelitian (seperti sejarah, testing, seleksi, dan regresi yang dapat memengaruhi tingkat keberhasilan penelitian).

\section{SIMPULAN}

Dilihat dari data kuantitatif, bimbingan kelompok dengan pengajaran formula ABCDE pendekatan rasional emotif behavior belum efektif dalam meningkatkan self efficacy mahasiswa calon guru. Ada beberapa faktor yang memengaruhi seperti self efficacy mahasiswa yang mengikuti penelitian ini sebagian besar sudah tinggi (hasil pretest) sehingga secara kuantitatif menyatakan tidak ada peningkatan self efficacy (tidak menunjukkan perubahan skor yang besar/ tidak tercapai skor maksimum) dan sebaiknya lebih tepat diterapkan untuk mahasiswa self efficacy kategori rendah dan sedang. Dari data kualitatif didapatkan bahwa mahasiswa menyadari akan masalahnya, menyadari ada penyebab keyakinan irasional penyebab masalah, memahami cara mengatasinya sehingga mahasiswa merasa ada keyakinan akan kemampuan untuk menjadi guru dan akan menerapkan materi yang didapat dalam menyelesaikan masalah sendiri khususnya terkait self efficacy menjadi guru di masa mendatang. Berdasarkan temuan hasil penelitian dan pembahasan, dapat diketahui bahwa desain intervensi pada penelitian ini dapat diterapkan untuk meningkatkan self efficacy mahasiswa calon guru apabila dilakukan perbaikan terlebih dahulu pada keterbatasan penelitian ini. Desain intervensi ini setelah diperbaiki pada pelaksanaannya akan dapat juga diterapkan selain untuk meningkatkan self efficacy.

\section{DAFTAR RUJUKAN}

Aini, L. K. \& Nursalim, M. (2012). Penerapan Bimbingan Kelompok dengan Teknik Sosiodrama untuk Meningkatkan Kemampuan Interaksi Sosial Siswa di Lingkungan Sekolah. Jurnal Psikologi Pendidikan dan Bimbingan, 13(1), 83-92.

Arifin, M., Putro, S. C., \& Putranto, H. (2014). Hubungan Kemampuan Efikasi Diri Dan Kemampuan Kependidikan Dengan Kesiapan Menjadi Guru TIK Mahasiswa Pendidikan Teknik Informatika. Teknologi dan Kejuruan, 37(2),129-136. 
Arslan, A. (2012). Predictive Power of The Sources of Primary School Students Self-Efficacy Beliefs on Their Self-efficacy Beliefs for Learning and Performance. Educational Sciences: Theory \& Practice, 12(3), 1915-1920.

Bandura. (1997). Self-efficacy: TheEexercise of Control. New York: W. H. Freeman Company.

Brandon, D.P. (2000). Self efficacy: Gender Differences of Prospective Primary Teachers in Botswana. Research in Education, 64(1), 36-43.

Corey. (2009). Teori dan Praktek Konseling Psikoterapi. Bandung: PT Refika Aditama.

Creswell, J.W. (2010). Research Design Pendekatan Kualitatif, Kuantitatif dan Mixed. Yogyakarta: Pustaka Pelajar.

Creswell, J.W. (2012). Educational Research;Planning, Conducting, and Evaluating Quantitative and Qualitative Research. United States of America: Pearson.

Eroglu, C., \& Unlu, H. (2015). Self-Efficacy: Its Effects on Physical Education Teacher Candidates' Attitudes Toward the Teaching Profession. Educational Sciences: Theory and Practice, 15(1), 201-212.

Ghufron, M. N. \& Rini R.S. (2011).Teori-teori Psikologi. Jogjakarta: Ar-Ruzz Media.

Goddard,R.D., Hoy, W.K.,\& Woolfolk Hoy, A. (2000). Collective Teacher Efficacy: Its Meaning, Measure, and Impact on Student Achievement. American Educational Research Journal, 37(2), 479-507.

Handika, I. W., Putri, D. A. W. M., Ps, S., \& Suarni, N. K. (2014). Penerapan Konseling Rasional Emotif dengan Formula ABC untuk Meningkatkan Percaya Diri Siswa Kelas VII 2 SMP Laoratorium Undiksha 2013/2014. Jurnal Ilmiah Bimbingan Konseling, 2(1).

Leyser, Y., Zeiger, T., \& Romi, S. (2011). Changes in Self Efficacy of Prospective Special and General Education Teachers: Implication for Inclusive Education. International Journal of Disability, Development and Education, 58(3), 241-255.

Lian, L.L. \& Richardson, G.M. (2009). Enhancing Prospective Teachers' Science Teaching Efficacy Beliefs Through caffolded, Student-Directed Inquiry. Journal of Elementary Science Education, 21(1), 51-66.

Natawidjaja, R. (1987). Pendekatan dalam Penyuluhan Kelompok. Jakarta: Depdikbud.

Permendiknas. (2007). Standar Kualifikasi Akademik dan Kompetensi Guru. Jakarta: Kemendikbud.

Pinchevsky, N., \& Bogler, R. (2014). The Influence of Teachers' Perceived Self-Efficacy and Role Impact on their Preferences in Adopting Strategies to Resolve Conflict Situations with Students. International Studies in Educational Administration (Commonwealth Council for Educational Administration \& Management (CCEAM)), 42(2) 111-125.

Putra, S. A., Daharnis. D., Syahniar., S. (2013). Efektivitas Layanan Bimbingan Kelompok dalam Meningkatkan Self efficacy Siswa. Konselor, 2(2), 1-6.

Raelin, J. A., Bailey, M. B., Hamann, J., Pendleton, L. K., Reisberg, R., \& Whitman, D. L. (2014). The Gendered Effect of Cooperative Education, Contextual Support, and Self Efficacy on Undergraduate Retention. Journal of Engineering Education, 103(4), 599-624.

Tschannen-Moran, M., Hoy, A. W.,\& Hoy, W.K. (1998). Teacher Efficacy: Its Meaning and Measure. Review of Educational Research, 68(2), 202-248.

Tschannen-Moran, M.,\& Woolfolk-Hoy, A. I2001. Teacher Efficacy: Capturing an Elusive Construct. Teaching and Teacher Education, 17(7), 783-805.

Velthuis, C., Fisser, P., \& Pieters, J. (2014). Teacher Training and Pre-service Primary Teachers' Selfefficacy for Science Teaching. The Association for Science Teacher Education, 25(4). 445-464.

Willis, S.S. (2014). Konseling Individual (Teori dan Praktek). Bandung: Alfabeta. 